\title{
MINIMALLY INVASIVE SPINE SURGERY IN THE NUEVO HOSPITAL CIVIL DE GUADALAJARA "DR. JUAN I. MENCHACA"
}

\author{
CIRURGIA DE COLUNA MINIMAMENTE INVASIVA NO NUEVO HOSPITAL CIVIL \\ DE GUADALAJARA "DR. JUAN I. MENCHACA" \\ CIRUGÍA DE COLUMNA MÍNIMAMENTE INVASIVA EN EL NUEVO HOSPITAL CIVILDE GUADA- \\ LAJARA "DR. JUAN I. MENCHACA"
}

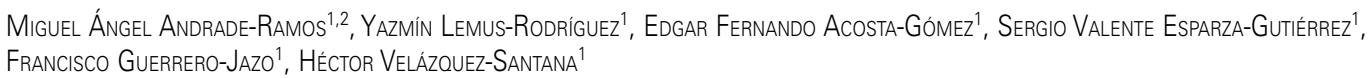

1. Nuevo Hospital Civil de Guadalajara “Dr. Juan I. Menchaca", Department of Neurosciences, Neurosurgery Service, Guadalajara, Jalisco, Mexico.

2. Universidad de Guadalajara, Centro Universitario de Ciencias de la Salud (CUCS), Division of Clinical Disciplines, Department of Medical Clinics, Guadalajara, Jalisco, Mexico.

\begin{abstract}
Objective: To describe our experience on a case series treated with minimal invasive techniques in spine surgery, with short-term follow-up and identify complications. Methods: A prospective analysis was performed on 116 patients operated on by the same team from September 2015 to June 2016. Evaluating the short-term follow-up we registered the surgical time, bleeding, complications, hospital stay, pre- and postoperatively neurological status, as well as scales of disability and quality of life. Demographic and surgical procedure data were analyzed with SPSS version 20 program. Results: A total of 116 patients with a mean age of $49.7+15.7$ (21-85 years) underwent surgery being 76 (65\%) with lumbar conditions and $37(32 \%)$ with cervical conditions. The most common procedures were tubular discectomies (31), tubular bilateral decompression (17), lumbar MI-TLIFs (7), and anterior cervical discectomy and fusion (35). The mean blood loss was $50.6 \mathrm{cc}$, the hospital stay was 1.7 day, pre- and postoperative pain VAS were $7.4 \%$ and $2.3 \%$, respectively, pre- and postoperative Oswestry (ODI) were $64.6 \%$ and $13.1 \%$, respectively, pre- and postoperative SF-36 of $37.8 \%$ and 90.3\%. There were no major complications, except for a surgical wound infection in diabetic patient and three incidental durotomies, one of these being a contained fistula, treated conservatively. Conclusions: The current tendency towards minimally invasive surgery has been justified on multiple studies in neoplastic and degenerative diseases, with the preservation of the structures that support the spine biomechanics. The benefits should not replace the primary objectives of surgery and its usefulness depends on the skills of the surgeon, pathology and the adequate selection of the techniques. We found that the tubular access allows developing techniques such as discectomy, corpectomy and fusion without limiting exposure, avoiding manipulation of adjacent structures, reducing complications and being feasible in a public hospital.
\end{abstract}

Keywords: Spine/surgery; Minimally invasive surgical procedures; Treatment outcome; Prospective studies.

\section{RESUMO}

Objetivo: Descrever nossa experiência em uma série de casos tratados por técnicas minimamente invasivas de cirurgia da coluna, o acompanhamento a curto prazo e identificar complicações. Métodos: Realizou-se análise prospectiva de 116 pacientes operados pela mesma equipe, de setembro de 2015 até junho de 2016. Avaliando o acompanhamento a curto prazo, foram registrados tempo cirúrgico, hemorragia, complicações, estadia hospitalar, estado neurológico pré e pós-operatório, além de escalas de incapacidade e qualidade de vida. Os dados demográficos e sobre o procedimento cirúrgico foram analisados com o programa SPSS versão 20. Resultados: Um total de 116 pacientes com média de idade de 49,7 + 15,7 (21 a 85 anos) foram operados, sendo 76 (65\%) com afecção lombar e 37 (32\%) com afecção cervical. Os procedimentos mais comuns foram discotomias tubulares (31), descompressão bilateral tubular (17), MI-TLIF (7) lombares; discotomia e artrodese anterior (35). O sangramento médio foi de $50,6 \mathrm{~cm}^{3}$, o tempo de hospitalização foi 1,7 dia, a escala EVA pré-cirúrgica foi 7,4 e a pós-cirúrgica 2,3, Oswestry (ODI) pré-cirúrgico de 64,6\% e pós-cirúrgico de 13,1\%, SF-36 pré-cirúrgico de $37,8 \%$ e pós-cirúrgico de 90,3\%. Não houve grandes complicações, exceto uma infecção da ferida cirúrgica em paciente diabética e três durotomias incidentais um dos pacientes com fístula, uma delas contida, tratada de modo conservador. Conclusões: A tendência atual da cirurgia minimamente invasiva tem sido justificada em vários estudos sobre neoplasia e doenças degenerativas, preservando as estruturas da biomecânica da coluna vertebral. Os benefícios não devem substituir os objetivos primários e sua utilidade depende das habilidades do cirurgião, da patologia e do uso seletivo das técnicas. Constatamos que o acesso tubular permite desenvolver a técnica de discotomia, fusão e corpectomia sem limite de exposição, evitando manipulação de estruturas adjacentes, reduzindo as complicações e sendo viável em hospitais públicos.

Descritores: Coluna vertebral/cirurgia; Procedimentos cirúrgicos minimamente invasivos; Resultado do tratamento; Estudos prospectivos.

\section{RESUMEN}

Objetivo: Describir nuestra experiencia en una serie de casos tratados mediante técnicas mínimamente invasivas en cirugía de columna, su seguimiento a corto plazo e identificar las complicaciones. Métodos: Se realizó un análisis prospectivo en 116 pacientes intervenidos

Study conducted at the Nuevo Hospital Civil de Guadalajara “Dr. Juan I. Menchaca”, Department of Neurosciences, Neurosurgery Service, Guadalajara, Jalisco, Mexico.

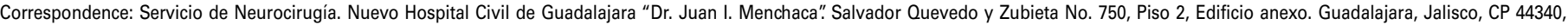
Mexico. miguelandrade11@ hotmail.com 
por el mismo equipo desde septiembre de 2015 a junio de 2016. Evaluando el seguimiento a corto plazo, se registró tiempo quirúrgico, sangrado, complicaciones, estancia hospitalaria, estado neurológico pre y post operatorio además de escalas de discapacidad y calidad de vida. Los datos demográficos y del procedimiento quirúrgico fueron analizados con el programa SPSS versión 20. Resultados: Un total de 116 pacientes con edad promedio de 49,7 + 15,7 (21 a 85 años), fueron intervenidos siendo 76 (65\%) patologías lumbares y 37 (32\%) cervicales. Los procedimientos más comunes fueron discectomías tubulares (31), descompresión bilateral tubular (17), MI-TLIF (7) lumbares; discectomía y artrodesis anterior (35). El promedio de sangrado fue 50,6 cc, estancia hospitalaria 1,7 día, escala EVA prequirúrgica 7,4 y posquirúrgica 2,3, Oswestry (ODI) prequirúrgico 64,6\% y posquirúrgico 13,1\%, SF-36 prequirúrgico 37,8\% y posquirúrgico 90,3\%. No hubo complicaciones mayores, excepto una infección de herida quirúrgica en paciente diabética y 3 durotomías incidentales, una de estas con fístula contenida, de manejo conservador. Conclusiones: La tendencia actual de la cirugía mínimamente invasiva se ha justificado en múltiples estudios en patología tumoral y degenerativa, con la conservación de estructuras para biomecánica de la columna. Los beneficios no deben reemplazar los objetivos primarios y su utilidad depende de las habilidades del cirujano, la patología, y el uso selectivo de las técnicas. Encontramos que el acceso tubular permite desarrollar la técnica de discectomía, fusión y corpectomía sin limitar la exposición, evitando manipulación de estructuras adyacentes, disminuyendo complicaciones y siendo factible en un hospital público.

Descriptores: Columna vertebral/cirugía; Procedimientos quirúrgicos mínimamente invasivos; Resultado del tratamiento; Estudios prospectivos.

\section{INTRODUCTION}

Minimally invasive spine surgery causes the least possible aggression to the tissues of the patients, which leads to fewer complications with shorter hospital stays and earlier reintegration into their daily activities. ${ }^{1-11}$

The particular characteristics of spine surgery require advances to be made prudently and more safely than in surgeries in other regions of the human body. In spite of the existing difficulties, the possibility of using techniques labeled "minimally invasive" in the spine is perhaps more important and sustainable than in other parts of the organism. ${ }^{1,2}$ It is for this reason that there have been advances in minimally invasive techniques in spine surgery in recent years. ${ }^{2}$

Approaches from the posterior part of the spine severely injure the posterior musculature with irrecoverable denervation and are a significant cause of surgical failure. ${ }^{1,3-11}$ Anterior spinal approaches require thoracotomies, laparotomies, lumbotomies, etc., all of which offer broad exposure but also severe injury to the adjacent tissues with undesirable, and sometimes definitive, secondary effects. ${ }^{12-15}$ It is important to achieve outcomes similar to those of conventional surgery without most of its inconveniences of unnecessary damage to adjacent tissues. This is why the benefits obtained from minimally invasive techniques are not limited only to the size of the incision, but also to a less painful postoperative period and the possibility for the patient to return more rapidly to their day-to-day life. ${ }^{2-11}$

\section{METHOD}

We present a series of 116 cases of patients with different common spinal pathologies that were resolved using minimally invasive surgical techniques, with the objective of evaluating the short-term clinical follow-up. Patients treated during the period from September, 2015, to June, 2016, at the Nuevo Hospital Civil de Guadalajara "Dr. Juan I. Menchaca" were included in the study. Patients who signed the informed consent form underwent surgery performed by the same surgical team using these techniques. For each patient surgical time, blood loss, complications, hospitalization time, and pre- and postoperative neurological conditions were recorded. Disability and quality of life scales were also applied and the demographic and surgical procedure data were analyzed using the SPSS version 20 program. Each patient signed the informed consent form for admission to the hospital for research purposes and the study was authorized by the Institutional Review Board of the Hospital Civil "Dr. Juan I Menchaca", with number 035/16HCJIM/2016.

\section{RESULTS}

Of the 116 patients who underwent spine, surgery using minimally invasive techniques, 60 (51\%) were women. The average age of the patients was $49.7+15.7(21-85)$. Of the 116 procedures, 76 $(65 \%)$ were in the lumbar spine: discectomy by tubular approach (31 cases), bilateral decompression of lumbar spinal stenosis by tubular approach (17 cases), interlaminar decompression of narrow canal using the Hatta technique (3 cases), reinforcement of vertebral bodies with bone cement via kyphoplasty by unilateral percutaneous extrapedicular (3 cases) and bipedicular (2 cases) approaches, unilateral approach vertebroplasty (6 cases), transforaminal lumbar interbody fusion MI-TLIF (7 cases), mini-open lumbar discectomy (1 case), mini-open posterolateral fusion (4 cases), laminotomy and teratoma resection (1 case), and MI-LECA (1 case).

Thirty-seven (32\%) patients underwent cervical spine surgery: ACDF (anterior cervical discectomy and fusion) (35 cases), posterior laminoforaminotomy with disc hernia resection by tubular approach (1 case), and posterior tubular laminoforaminotomy (1 case). The average bleed was $50.6 \mathrm{cc}$ and the average length of hospitalization was 1.7 days. (Table 1 )

The preoperative average score for the visual analog scale (VAS) was 7.4 and the postsurgical average was 2.3. The preoperative average score for the Oswestry Disability Index (ODI) was 64.6\% and the postsurgical average was $13.1 \%$. The preoperative average for the SF-36 questionnaire was $37.8 \%$ the postsurgical average was $90.3 \%$. There were no major complications in this case series. There was one case of superficial infection at the surgical site in a diabetic patient with wound closure on the second attempt, 3 incidental durotomies, one of which had a contained fistula that diminished with rest.

\section{DISCUSSION}

In general, the objectives of spine surgery are to recover the quality of life and relieve the pain that afflicts the patient through neurodecompression, to preserve segmental function, to reinstate segmental balance through the restoration of spaces and multiplane balance, to correct deformity, and to stabilize. .11,16-18 $^{10}$

These objectives are achieved through conventional spinal approaches that involve the detachment of the paraspinal musculature, its denervation and devascularization, in addition to injury to the ligamentary structures, in contrast to minimally invasive techniques, which try to minimize the damage to these structures. Minimally invasive techniques are able to limit exposure as much as possible and to reduce the retraction of the structures, resulting in the less collateral damage to the tissues, a measurable reduction in morbidity, and above all, a more rapid functional recovery without departing from the primary objective established for spine surgery. ${ }^{2-11}$

The current trend in neurosurgery for spine pathologies is to perform a surgery using minimally invasive techniques. Several prior studies established a valid justification for this type of procedure in terms of their similar results in neurological outcomes and the preservation of structures that are essential to the biomechanics of the spine. ${ }^{1-11,16-18}$

Minimally invasive approaches have been developed for degenerative, traumatic, and neoplastic pathologies, among others. ${ }^{2-1}$ This development is associated with the technological advances in minimally invasive techniques, including neuroimaging, specialized retractors, neuronavigation, etc. ${ }^{1}$ (Figure 1) 
Table 1. Minimally invasive spinal procedures at the Nuevo Hospital Civil de Guadalajara "Dr. Juan I. Menchaca" (Sep 2015 to Jun 2016$).$

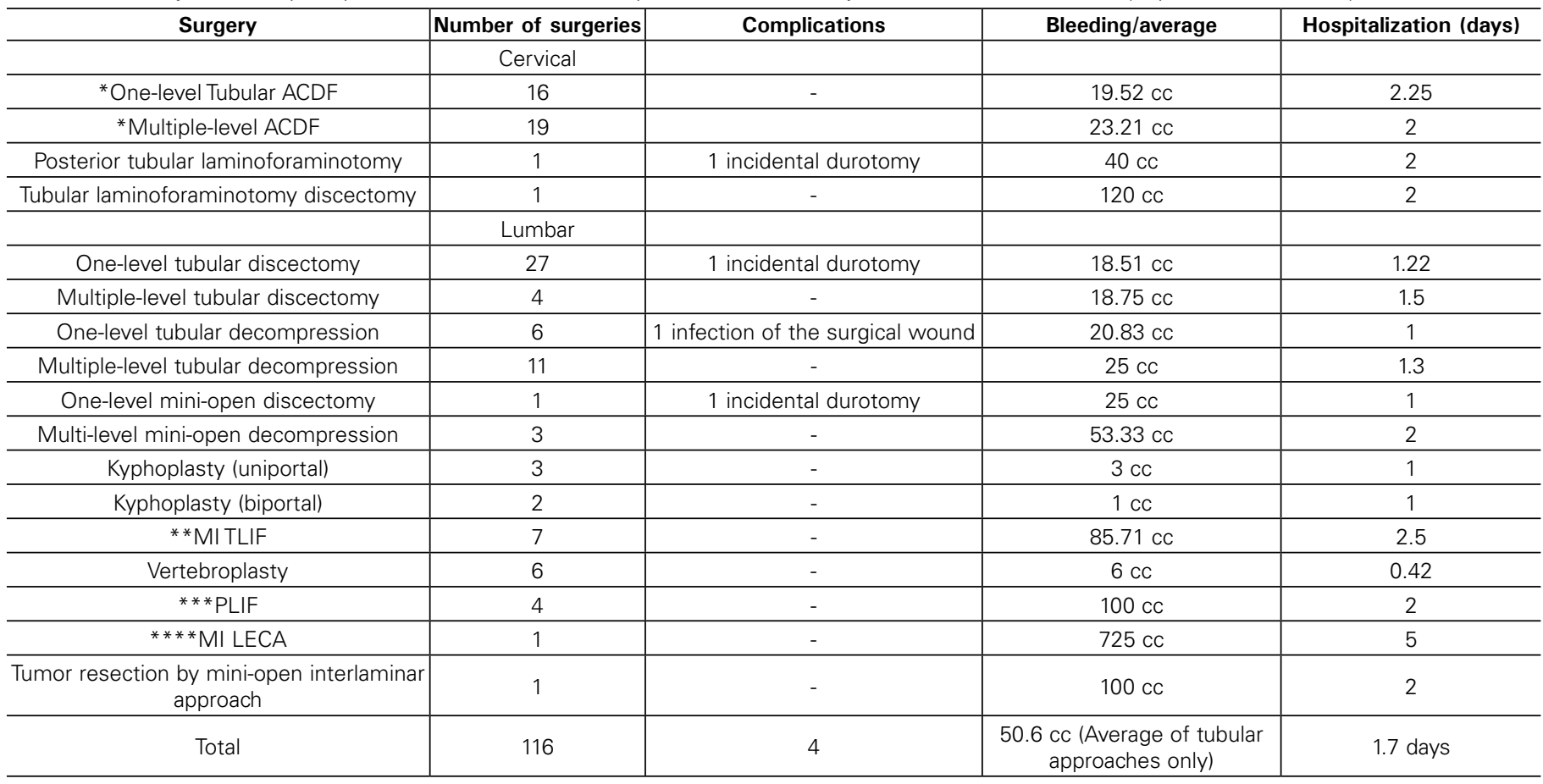

*Anterior cervical discectomy and fusion; **Minimally invasive transforaminal lumbar interbody fusion; ${ }^{* \star \star M i n i-o p e n ~ p o s t e r o l a t e r a l ~ l u m b a r ~ i n t e r b o d y ~ f u s i o n ; ~ * * \star \star ~ L a t e r a l ~ e x t r a c a v i t a r y ~ a p p r o a c h ~ c o r p e c t o m y ~}$

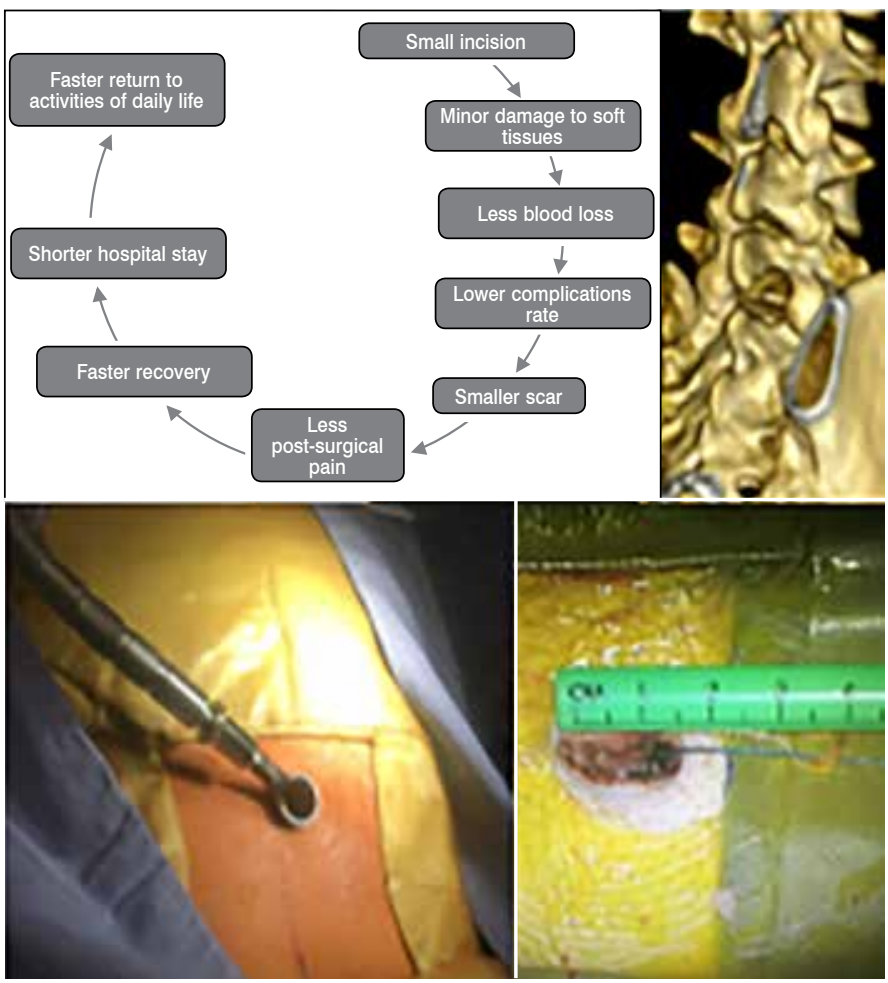

Figure 1. Advantages of minimally invasive spine surgery.

In our case series, most of the surgeries were performed via anterior, lateral, and posterior tubular approaches to the spine, principally in the cervical and lumbar regions, to treat everything from disc extrusions to tumor resections and corpectomies, with outcomes similar to those found in the literature, achieving the objectives of spine surgery, reducing the rate of complications, with a shorter hospitalization, which, in a public hospital, is favorable towards the scheduling of elective surgery and wait times. (Figures 2, 3, and 4)

Within our case series, besides degenerative pathologies such as the MI-TLIF procedures, (Figure 5) the resection of a lumbar teratoma

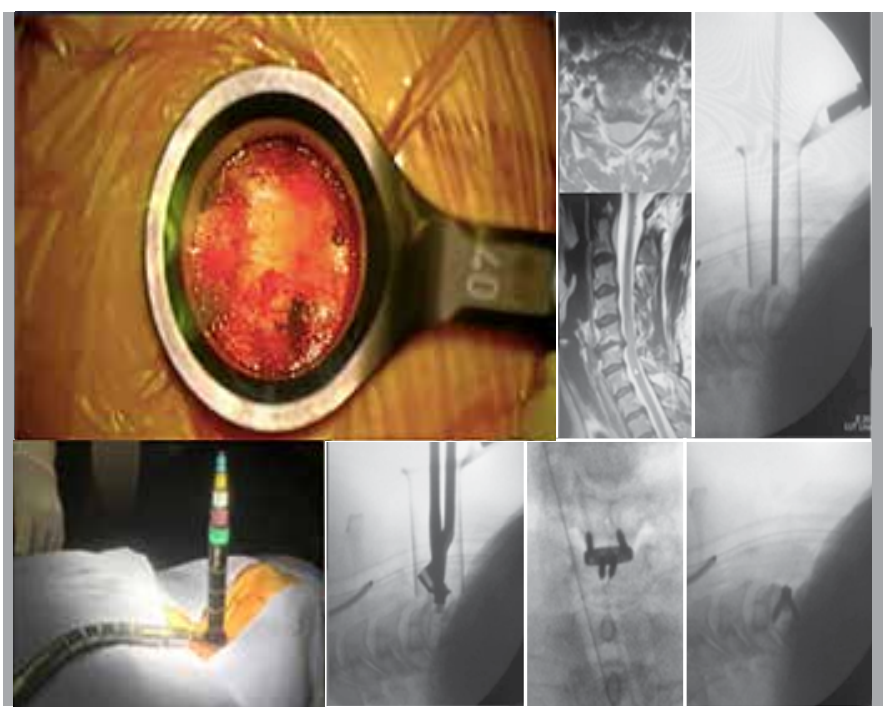

Figure 2. Anterior C5-C6 cervical discectomy and tubular fusion.

via mini-open approach was also possible, without the development of complications, with adequate exposure, a reduction in bleeding, and a shorter hospital stay. (Figure 6)

The most common procedure in our series was the lumbar tubular discectomy, for which a recent double-blind study reported results similar to those of conventional microdiscectomy and concluded that neither technique was superior to the other. ${ }^{19,20}$

Among our complications, incidental durotomy, which is reported as rare in these procedures, occurred in $2.5 \%$.

In a large cases series it was reported as $1.6 \%,{ }^{21}$ its closure being difficult due to the manipulation of the instruments in tubular approaches. ${ }^{22}$ We managed them using hemostatic sponges, fibrin glue, and adequate closure of fascia and skin, with rest for two days. Because of the minimally invasive nature, closure of the soft tissues over the defect without dead space is sufficient to prevent the development of an external cerebrospinal fluid fistula as reported by Shibayama. ${ }^{23}$ 


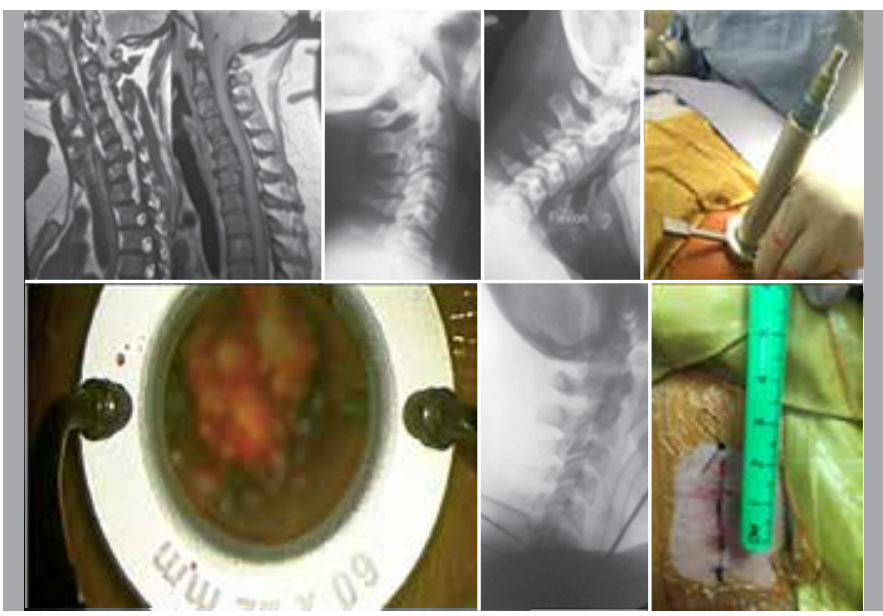

Figure 3. Posterior C6-C7 cervical discectomy and tubular laminoforaminotomy.

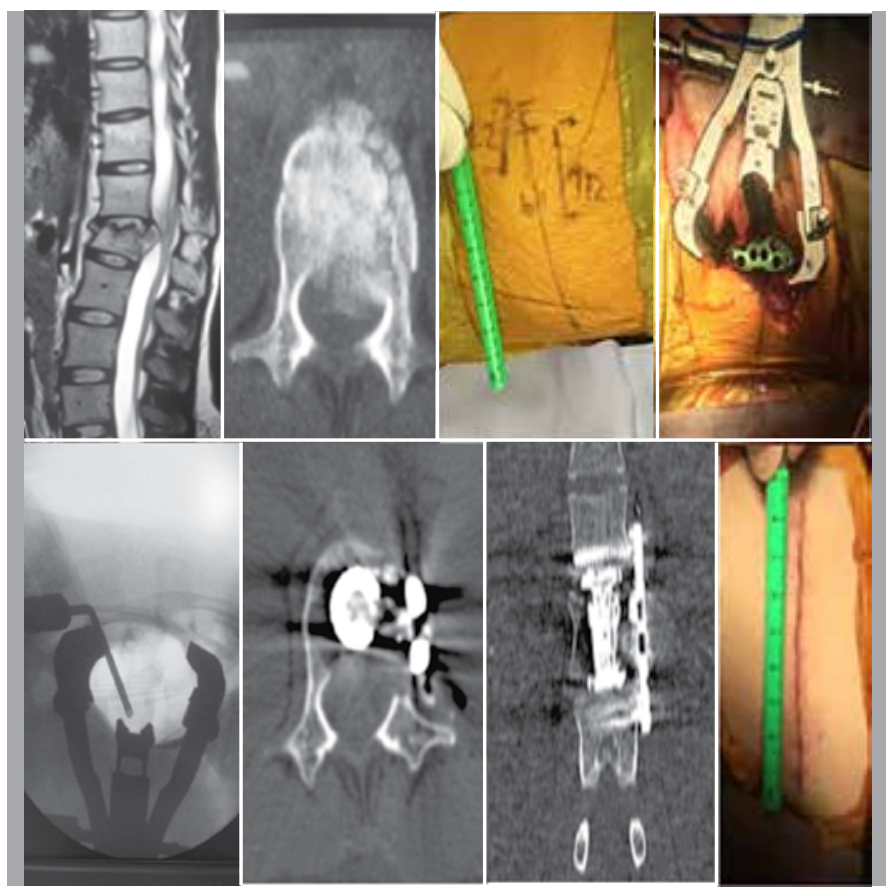

Figure 4. MI-LECA, Lateral L1 extracavitary corpectomy.

\section{CONCLUSIONS}

The benefits of minimally invasive spine surgery should never override the main surgical objectives and using it depends on the abilities of the surgeon and the pathology of the patient. Selective use of the available technology can offer better outcomes.

The tubular approach to the anterior, posterior, and lateral spine allows the development of the techniques of discectomy, fusion, and corpectomy without limiting exposure and avoiding manipulation of the adjacent structures, which drastically reduces the immediate

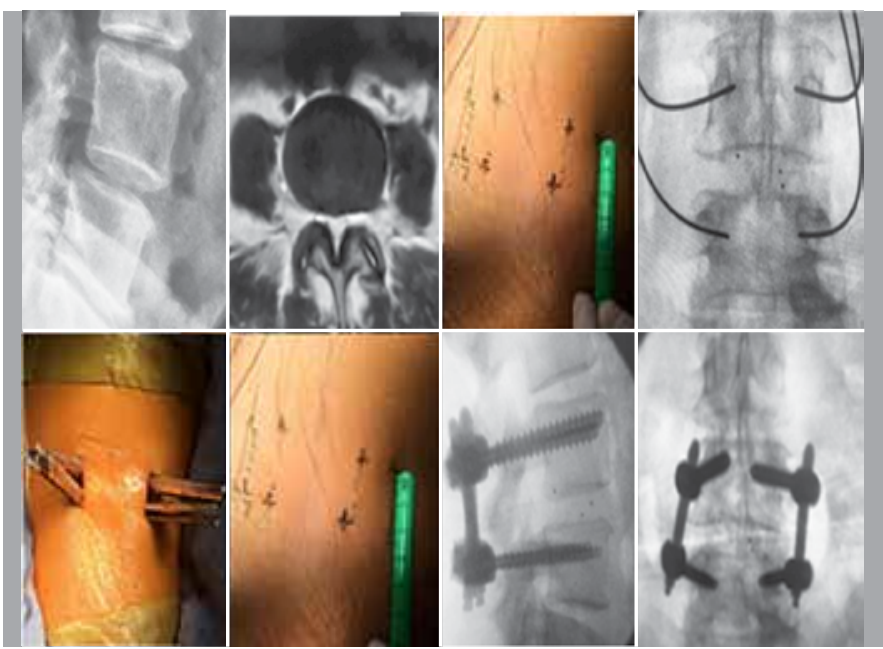

Figure 5. MI-TLIF, Minimally invasive transforaminal lumbar interbody fusion.

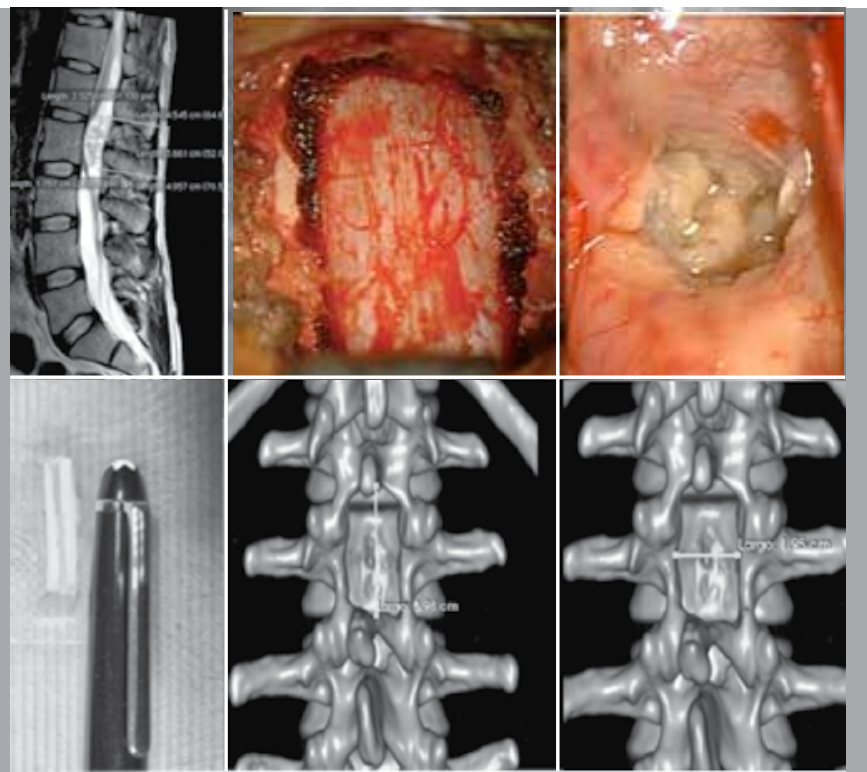

Figure 6. Mini-open interlaminar L1-L2 lumbar teratoma tumor resection.

complications of conventional approaches, and performing these techniques is feasible in a public hospital.

\section{ACKNOWLEDGEMENTS}

We thank the directors of the OPD Hospital Civil de Guadalajara for promoting the development of new surgical advances to benefit patients among the medical staff of the Department of Neurosurgery.

All the authors declare that there are no potential conflicts of interest regarding this article.

CONTRIBUTION OF THE AUTHORS: Each of the authors made significant individual contributions to the development of the manuscript. MAAR and HVS were the main contributors to the writing of the manuscript. SVEG, common knowledge, YLR, EFAG and MAAR, performed the surgeries and patient follow-up, and collected clinical data. FGJ evaluated the statistical analysis data. MAAR and HVS researched the literature, reviewed the manuscript, and contributed to the intellectual concept of the study.

\section{REFERENCES}

1. Lian X, Navarro-Ramirez R, Berlin C, Jada A, Moriguchi Y, Zhang Q, et al. Total 3D Airo@ Navigation for Minimally Invasive Transforaminal Lumbar Interbody Fusion. Biomed Res Int. 2016;2016:5027340.

2. Brodano GB, Martikos K, Lolli F, Gasbarrini A, Cioni A, Bandiera S, et al. Transforaminal lumbar interbody fusion in degenerative disk disease and spondylolisthesis grade I: minimally invasive versus open surgery. J Spinal Disord Tech. 2015;28(10):E559-64.

3. Dhall SS, Wang MY, Mummaneni PV. Clinical and radiographic comparison of mini-open transforaminal lumbar interbody fusion with open transforaminal lumbar interbody fusion 
in 42 patients with long-term follow-up. J Neurosurg Spine. 2008;9(6):560-5.

4. Shunwu F, Xing Z, Fengdong Z, Xiangqian F. Minimally invasive transforaminal lumbar interbody fusion for the treatment of degenerative lumbar diseases. Spine (Phila Pa 1976). 2010;35(17):1615-20.

5. Foley KT, Holly LT, Schwender JD. Minimally invasive lumbar fusion. Spine (Phila Pa 1976). 2003;28(15 Suppl):S26-35.

6. German JW, Foley KT. Minimal access surgical techniques in the management of the painful lumbar motion segment. Spine (Phila Pa 1976). 2005;30(16 Suppl):S52-9.

7. Scheufler KM, Dohmen H, Vougioukas VI. Percutaneous transforaminal lumbar interbody fusion for the treatment of degenerative lumbar instability. Neurosurgery. 2007;60(4 Suppl 2):203-12; discussion 212-3.

8. Guiot BH, Khoo LT, Fessler RG. A minimally invasive technique for decompression of the lumbar spine. Spine (Phila Pa 1976). 2002;27(4):432-8.

9. Khoo LT, Palmer S, Laich DT, Fessler RG. Minimally invasive percutaneous posterior lumbar interbody fusion. Neurosurgery. 2002;51(5 Suppl):S166-81.

10. Lee DY, Jung TG, Lee SH. Single-level instrumented mini-open transforaminal lumbar interbody fusion in elderly patients. J Neurosurg Spine. 2008;9(2):137-44.

11. Mummaneni PV, Rodts GE Jr. The mini-open transforaminal lumbar interbody fusion Neurosurgery. 2005:57(4 Suppl):256-61; discussion 256-61.

12. Rankin D, Mathew PS, Kurnutala LN, Soghomonyan S, Bergese SD. Tension pneumothorax during surgery for thoracic spine stabilization in prone position: a case report and review of literature. J Investig Med High Impact Case Rep. 2014;2(2):2324709614537233.

13. Latalski M, Fatyga M, Gregosiewicz A. Problems and complications in VEPTR-based treatment. Ortop Traumatol Rehabil. 2011:13(5):449-55.

14. Aichmair A, Fantini GA, Garvin S, Beckman J, Girardi FP. Aortic perforation during lateral lumbar interbody fusion. J Spinal Disord Tech. 2015;28(2):71-5.
15. Flouzat-Lachaniette $\mathrm{CH}$, Delblond W, Poignard A, Allain J. Analysis of intraoperative difficulties and management of operative complications in revision anterior exposure of the lumbar spine: a report of 25 consecutive cases. Eur Spine J. 2013;22(4):766-74

16. Venkatesh R, Tandon V, Patel N, Chhabra HS. Solitary plasmacytoma of L3 vertebral body treated by minimal access surgery: Common problem different solution! J Clin Orthop Trauma. 2015;6(4):259-64

17. Afathi M, Peltier E, Adetchessi T, Graillon T, Dufour H, Fuentes S. Minimally invasive transmuscular approach for the treatment of benign intradural extramedullary spinal cord tumours: Technical note and results. Neurochirurgie. 2015;61(5):333-8.

18. Wong AP, Lall RR, Dahdaleh NS, Lawton CD, Smith ZA, Wong RH, et al. Comparison of open and minimally invasive surgery for intradural-extramedullary spine tumors. Neurosurg Focus. 2015;39(2):E11.

19. Arts MP, Brand R, van den Akker ME, Koes BW, Bartels RH, Peul WC. Tubular diskectomy vs conventional microdiskectomy for sciatica: a randomized controlled trial. JAMA 2009;302(2):149-58

20. Arts MP, Brand R, van den Akker ME, Koes BW, Bartels RH, Tan WF, et al. Tubular diskectomy vs conventional microdiskectomy for the treatment of lumbar disk herniation: 2-year results of a double-blind randomized controlled trial. Neurosurgery. 2011;69(1):135-44.

21. Wu X, Zhuang S, Mao Z, Chen H. Microendoscopic discectomy for lumbar disc herniation: surgical technique and outcome in 873 consecutive cases. Spine (Phila Pa 1976). 2006;31(23):2689-94.

22. Chou D, Wang VY, Khan AS. Primary dural repair during minimally invasive microdiscectomy using standard operating room instruments. Neurosurgery. 2009;64(5 Suppl 2):356-8.

23. Shibayama M, Mizutani J, Takahashi I, Nagao S, Ohta H, Otsuka T. Patch technique for repair of a dural tear in microendoscopic spinal surgery. J Bone Joint Surg Br. 2008;90(8):1066-7. 